\title{
Belgeo
}

Revue belge de géographie

2 | 2020

Peripheral borders, soft and hard re-bordering in Europe

\section{Cross-border cooperation on the external borders of the EU and the impact of the received EU CBC funds on AP Vojvodina/Serbia}

Imre Nagy

\section{CpenEdition}

\section{Journals}

Electronic version

URL: http://journals.openedition.org/belgeo/38732

DOI: 10.4000/belgeo.38732

ISSN: 2294-9135

Publisher:

National Committee of Geography of Belgium, Société Royale Belge de Géographie

Electronic reference

Imre Nagy, «Cross-border cooperation on the external borders of the EU and the impact of the received EU CBC funds on AP Vojvodina/Serbia », Belgeo [Online], 2 | 2020, Online since 07 May 2020, connection on 17 December 2020. URL : http://journals.openedition.org/belgeo/38732 ; DOI : https:// doi.org/10.4000/belgeo.38732

This text was automatically generated on 17 December 2020.

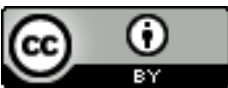

Belgeo est mis à disposition selon les termes de la licence Creative Commons Attribution 4.0 International. 


\title{
Cross-border cooperation on the external borders of the EU and the impact of the received EU CBC funds on AP Vojvodina/Serbia
}

\author{
Imre Nagy
}

\section{Introduction}

1 One of the priority areas of EU regional policy is assistance to cross-border cooperation realised over European Territorial Co-operation, within which the development of economically peripheral border areas is realised.

2 Territorial, regional and cross-border cooperation, through its development, has evolved from cooperation within the European Community, through the formation of Euroregions, opening up to Eastern European countries, and thus to economic development in - up to then - peripheral border regions. INTERREG I-V initiatives within the Community have played a significant role in this process, as well as the formation of Euroregions which have become focal points for binational (or multinational) initiatives that address specific economic, environmental, infrastructural and institutional problems affecting their respective regions (Scott, 2000; Blatter-Clement, 2000). Euroregions have later appeared on the external borders of the EU to the Western Balkans and Eastern Europe as well (Hungary-Serbia, PolandUkraine, Poland-Belorussia, Finland-Russia etc.), while the INTERREG III initiative together with the pre-accession funds (IPA, TACIS) for countries outside the EU participate in the development of border regions (Vovenda-Plotnikov, 2011). Beside the cross-border cooperation component within ETC, Transnational and Interregional cooperations have equally important role.

3 The European Union has established a new legal instrument, a new form of cooperation of the European Territorial Cooperation, namely European Groupings of Territorial 
Cooperation (Cohesion policy 2007-2013). It substantially contributes to European integration and to implementation of cross-border strategies. Furthermore, it brings EU policies closer to people; it means European, political, institutional and sociocultural added value.

Cross-border cooperation is also defined as institutionalised cooperation between regional and local authorities in the border area of neighbouring countries. Therefore thus cooperation within the EU and at the EU's external borders aim at managing issues that transcend the confines of individual communities - issues that include social affairs, economic development, minority rights, cross-border employment and trade, the environment etc. Transboundary co-operation also involves attempts to exploit borderlands situations, using borders as a resource for economic and cultural exchange, as well as for building political coalitions for regional development purposes (Perkmann, 2003; Popescu, 2008; Scott, 2015).

5 The exploration of border regions and cross-border relations took place along the EU's external borders in parallel with the development of the European Union's regional policy and the appreciation of border regions has been increasing since the eastern enlargement (in 2004 and 2007, 2013) (Fejes, 2013). However, regions located on Europe's external borders have not experienced a similar evolution under the auspices of the Greater Europe Initiative and the European Neighbourhood Policy (Nelles Walther, 2011), since EU funds could be quite useful in catching up and spatial development of the affected areas, but they are not sufficient, as their primary objective is to increase the networking of people living in border regions while the development of lagging areas is only a secondary objective (Ricz, 2018).

\section{Serbia as the external border of the EU}

6 During the nineties, following the change of regime in Central Eastern Europe and the civil war in Serbia, as a result of the EU's regional policy with the appreciation of the role of border regions, Serbia has been getting closer to the new EU Member States and the opportunities for cross-border cooperation have increased. For Serbia, this meant on the one hand that it can really enlarge its relations with the neighbours within the process of transition, and on the other hand that easier access to pre-accession funds was created through the implementation of strong cohesion relations, and the access to the funds was enabled (Fejes, 2013; Ricz, 2015).

7 Serbia's first encounter with cross-border cooperation, respecting the European Union's principles of cross-border cooperation, dates to the late 1990s when AP Vojvodina became a member of the Danube-Criş-Mureş-Tisa Euroregion. Unfortunately, this Euroregion is currently ineffective: in spite of the structural reform, the different political systems, the centralised, bureaucratic competences of the member states are still barriers in front of the cooperation (Fejes, 2013).

8 It is clearly visible that Serbia, which has started its pre-accession process from 2000 onwards, has implemented CBC relationships with 4 EU Member States ${ }^{2}$ between 2004 and 2013, which also means EU-support for cooperation along the external borders.

In the period 2004-2009 Serbia used PHARE CBC ${ }^{3}$ Hungary-Serbia for so-called "Pilot Small Projects Fund" to support local community development with a budget of EUR 600,000 , of which 17 projects were supported in Serbia. It enabled to explore a new type 
of application system, INTERREG III. The PHARE CBC-CARDS Romania-Serbia program has been aiming at establishing cohesion as well as socio-economic development since 2004. In this program, worth EUR 5.27 M, 20 projects were awarded to Serbia out of a total of 57 projects. In the period 2004-2006, Serbia joined the INTERREG IIIA crossborder co-operation program, since when Hungary joined the EU in 2004 it became a neighbouring country of the EU. In CBC projects, partners from Serbia are also funded by CARDS $^{4}$ funds.

During the 2007-2013 programming period, development funds were allocated to Serbia regarding two component of the IPA Programme Framework (1 - EU Institution Building, 2 - Cross-Border Relations Development). These resources allow for Serbia and all its neighbours both cross-border programs and developments within the country.

From the IPA components (2007-2013), the border regions (NUTS3 - districts) in Northern Serbia belong to the neighbouring programmes of IPA Hungary-Serbia and Croatia-Serbia, the border regions of Eastern Serbia belong to the neighbouring programmes Romania-Serbia, Hungary-Serbia and Bulgaria-Serbia, while the western border regions are involved in the neighbouring programmes Croatia-Serbia, SerbiaBosnia and Herzegovina, and Serbia-Montenegro (Nagy et al., 2015).

Participation in the SEE program (South East Europe Transnational Cooperation Program) was characteristic of universities, scientific institutions, chambers and institutes, thus this type of European cooperation is the subject of further research.

Unfortunately, no municipality from Serbia could integrate as part of an EGTC ${ }^{5}$ crossborder cooperation, since, even though the state ratified the Madrid Convention, it did not adopt by-laws that would allow municipalities to enter an EGTC (Fejes, 2013).

Figure 1. IPA programme areas of Western Balkan region (2007-2013).

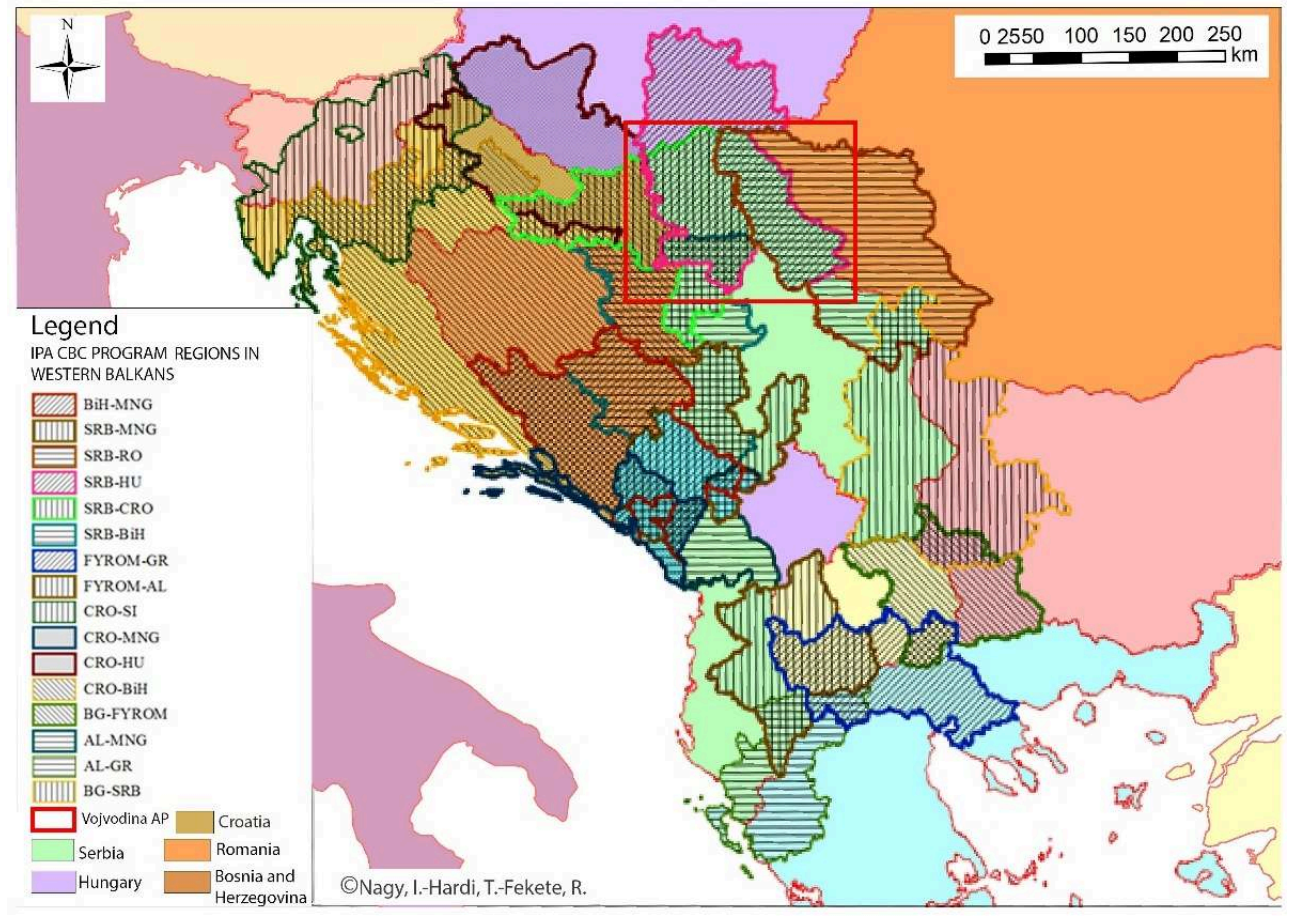

SOURCE: EDITED BY THE AUTHORS 

situated in the Pannonian Plain of Central Europe (21,506 km², 1.9 million inhabitants), has been included in the focus of our research because it is the most developed NUTS 2 region of Serbia, following Belgrade.

Vojvodina has a special location among the Western Balkan and Carpathian Basin regions. Due to its historical, ethnic, cultural and economic heritage, Vojvodina is one of the most valuable towards European Union, so called "gate" of Serbia and "bridge" between the Balkans and Carpathian regions. The historical and ethnical intension, geographical proximity and the European infrastructural connections have established the cross-border relations (Takács, 2008). Moreover, the province with one and a half million hectares of fertile arable land has great potentials for agriculture, agribusiness and renewable energy source utilisation. This area has long tradition in many branches of business, as well as the development of new industries, many financial and tax incentives (https://vojvodinahouse.eu/en/kancelarija-u-briselu/stranica/2/ovojvodini). Vojvodina has its own provincial government, and its area is bordering three EU countries, therefore EU support is more known here, and people are more interested in their use. The Province is a member of the Danube-Criş-Mureş-Tisa Euroregion, together with 2 Hungarian and 3 Romanian border regions. The Autonomous Province of Vojvodina is also a member of the Assembly of European Regions (AER) since 2002.

\section{Research methodology}

Monitoring and evaluating the impact of EU funds on local and regional development is an extremely complex process. Although there are adequate indicators, evaluation depends on a number of objective and subjective factors when analysing specific EU projects. Curković points out that “...despite the large financial resources the Commission has invested in supporting the Western Balkan countries to become members of the European Union, there are no mechanisms to measure the impact of this support on the accession process, or on the socio-economic change in these countries. The focus of assessing the impact of projects funded by EU IPA is only on internal or external monitoring of project implementation" (Ćurković-Mijačić 2012), which is of course one of the most important elements of evaluation, but beside these monitoring components, the content and presentation of essential indicators are lost.

17 The presented study monitors the impact of IPA programs (components 1 and 2 2007-2013), the created cross-border cohesion links between the regions, cities and settlements participating in the programs, as well as the sustainability and continuity of the created values of these projects. The impact of EU funds on local development was analysed on the basis of the number and value of implemented projects that were initiated by local governments ${ }^{6}$ or where they were involved in the projects (in Serbia, the basic level of local self-government is the "municipality" - a central settlement and smaller settlements gravitating to it), as well as based on visible results, and opinions regarding the implementation of these projects. The database made by the Association of Independent Journalists of Vojvodina was used, which has been made systematically and shows relevant project data in 44 local governments of AP Vojvodina, as well as available official results of the IPA program for Serbia. We performed analysis based on these data, focusing on prosperous cross-border networks of interested communities to 
determine: what positions they have and what the weight of the border settlements is in the network of cooperation in horizontal sense, as well as to allocate those 10 municipalities where further local government research was conducted. The analysis, which focused on financial implementation, sustainability and impact on the work of local governments, was carried out evenly across Vojvodina, in municipalities of different economic development level, during which interviews were conducted with people who communicate with EU institutions in Serbia and seek to approximate these contents to local governments. In this analysis, we used an evaluation methodology in which the basic questions of the analysis relate to the establishment of partnerships for projects, sustainability of projects, financial and human resource capacity problems related to project implementation, and financial realisation. Moreover, the concrete results of territorial and local development were in focus, as well as to reveal what local governments have learned about the EU and EU funding, and what the other open issues and problems of project generation were. The analysis of the municipalities covered:

- total sum of effective financial subsidies to local government, or based on the funding proportion of certain municipalities per projects;

- realisation level of a project, because due to post financing local municipalities could get their share only after proving its financial and substantial realisation (there were several cases when financial realisation did not succeed);

- sustainability assessment of the projects, which is very important for strengthening and expanding an active and effective partnership, has been evaluated on the basis of:

- further formal communication with the project partners after project closure (1 point);

- further joint participation in (unsuccessful/successful) projects with former partners (2/3 points);

- new partner communication and co-operation in preparing new projects, where the workshops were followed by media (at least three times) (3 points);

- other successful joint participation in new projects with former partners (4 points);

- repeated successful application with the same and new partners (5 points).

In order to determine the relationship between the development level and the project absorption capacity of the municipalities and towns of Vojvodina, we used the single list of development of regions and local self-government units in Serbia (Uredba, 2014) and the categorisation of municipalities based on their IPA CBC fund absorption capacities (Ricz, 2018).

The classification of local self-government units by development is made on the basis of the value of gross domestic product per capita compared to the national average of Serbia ${ }^{7}$. The absorption capacity (AC) categories of the municipalities were determined by realized projects (high AC - 4 and more projects; medium AC - 2-3 projects; weak AC - 1 or 0 project).

\section{Territorial types of CBC}

Among the IPA 2007-2013 CBC grants, we examined only the cross-border cooperation of local governments, their problems, their territorial relations and the impact of these relationships, as well as the possibilities of future development. In this regard, we 
identified five spatial types of the territorial relationship, concerning $\mathrm{CBC}$ cooperation of the local governments in Serbia (Nagy, 2018):

- The borderline-related (symmetrical neighbourhood) co-operation territorial type - category 1, which is predestined by the designated border region, and is provided by the possibility of smooth border crossing: the density of border crossings to all three EU countries is 17-18 $\mathrm{km}$, including direct border relations, connections of the border-region centres Subotica (SER)-Szeged (HU); Baja (HU)-Sombor (SER), bike routes from both sides of the border crossing Novi Kneževac (SRB)-Újszentiván (HU), as well as daily migrations to attractive workplaces in Szeged, Kecskemét (Mercedes $\mathrm{GmbH}$ ) etc. There are no relevant statistics on new daily migration trends.

- The territorial type of the border region not related directly to the borderline - category 2, ethnically-related communities and municipalities: the "Hungarian-Hungarian" relations, the "Romanian-Romanian" relations, and in case of Croatia the "Serbian-Serbian" relations as well. All settlements with a significant Hungarian population maintain permanent economic, commercial, cultural, municipal and educational relations with the Hungarian border region. Similarly, the Romanian minority living in Serbia in the settlements near the Romanian border, alike other minorities, has maintained economic and commercial relations with the neighbouring Romanian settlements since Romania became an EU Member State. The Serbian-Croatian cross-border relationship is mainly manifested in the border relations between Serbs living in Croatia and Serbs living in Vojvodina (Ricz-NagyCsiszár, 2016).

- The $C B C$ type of regional centres - category 3. These are the $C B C$ relations of regional institutions which, according to EU regulations, have official relationship: Subotica (SER)Szeged (HU), Baja (HU)-Sombor (SER), Novi Sad (SER)-Szeged (HU), Novi Sad (SER)Kecskemét (HU); Novi Sad (SER)-Vukovar (CRO); Novi Sad (SER)-Timisoara (RO); Zrenjanin (SER)-Timisoara (RO); Vršac (SER)-Resica (RO).

- The irregular cross-border cooperation type - category 4 (e.g. the cities of Zagreb and Belgrade appear with implemented projects though they only belong to eligible IPA CBC areas);

- The $C B C$ connection with two or three countries - category 5. Where a local government maintains cross-border relations with two or three countries at the same time such as municipalities in North Vojvodina (Kanjiža, Novi Kneževac, Senta, Zrenjanin) that belong to two eligible IPA CBC areas (Hungary-Serbia and Romania-Serbia programs), or the municipalities of Šid, Odžaci, Subotica that can participate in Croatia-Serbia and Hungary-Serbia IPA CBC programs.

\section{Evaluation of the EU projects of the municipalities from Vojvodina}

21 The number of projects implemented by local governments (municipalities) was 256 in the period 2007-2013. However, regarding the size and spatial distribution of subsidies, there are large differences in Vojvodina. In the last planning cycle, the Local Government of Novi Sad ( $2^{\text {nd }}$ largest city in Serbia, with 408,276 inhabitants) realised 21 projects, but the project implementation of some other municipalities (14-18) was also significant. By contrast, five local governments realised only one project each, and one had no EU projects at all (Evropa u Vojvodini, 2015).

Most of the project proposals (45) were realised in the field of economic development, slightly fewer projects were used for municipal development, or they were related to 
environmental and nature protection, and the use of alternative energy sources (42-42), while the least number of projects were the educational ones (Tab. 1).

Table 1. Sectoral structure of grants in $\mathrm{CBC}$ projects.

\begin{tabular}{|l|l|l|l|l|}
\hline & HU-SER & RO-SER & CRO-SER & Total (million EUR) \\
\hline Road construction & 6,175 & & 502 & 6,677 \\
\hline Infrastructure planning & 1,678 & & 72 & 1,750 \\
\hline Hydro-infrastructure & 4,362 & & & 4,362 \\
\hline Economic development & 1,172 & 1,394 & 321 & 2,887 \\
\hline Regional planning & 1,146 & & & 1,146 \\
\hline Total & & & & 16,882 \\
\hline
\end{tabular}

SOURCE: ON THE BASIS OF IPA DATA

Figure 2. The total number of IPA projects ( $1^{\text {st }}$ and $2^{\text {nd }}$ components) by communities in Vojvodina AP, 2007-2013.

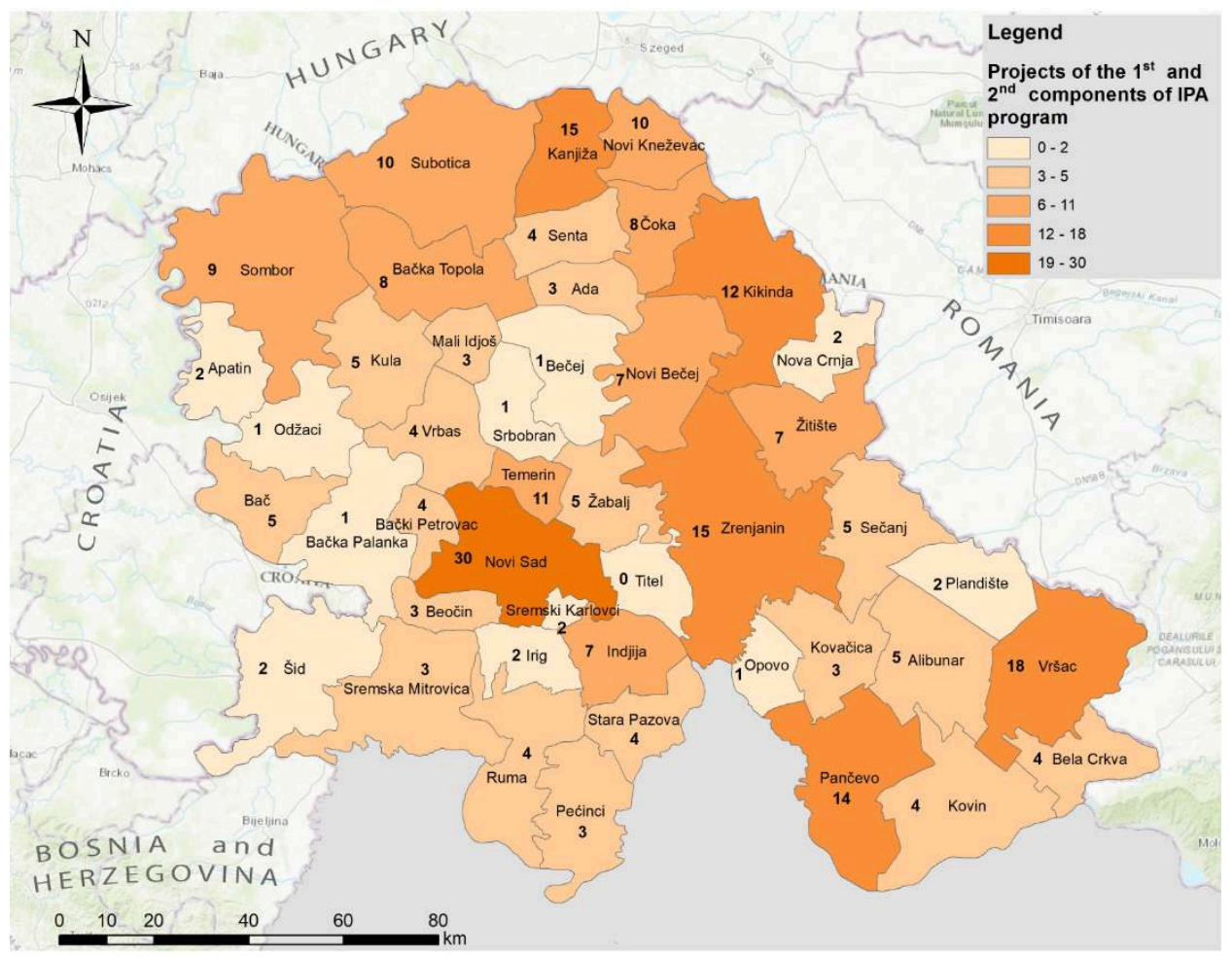

Source: On the basis of Nagy M. (2016) by the author 
Figure 3. Total value of the project budget (IPA projects $1^{\text {st }}$ and $2^{\text {nd }}$ components) by communities in Vojvodina AP, 2007-2013.

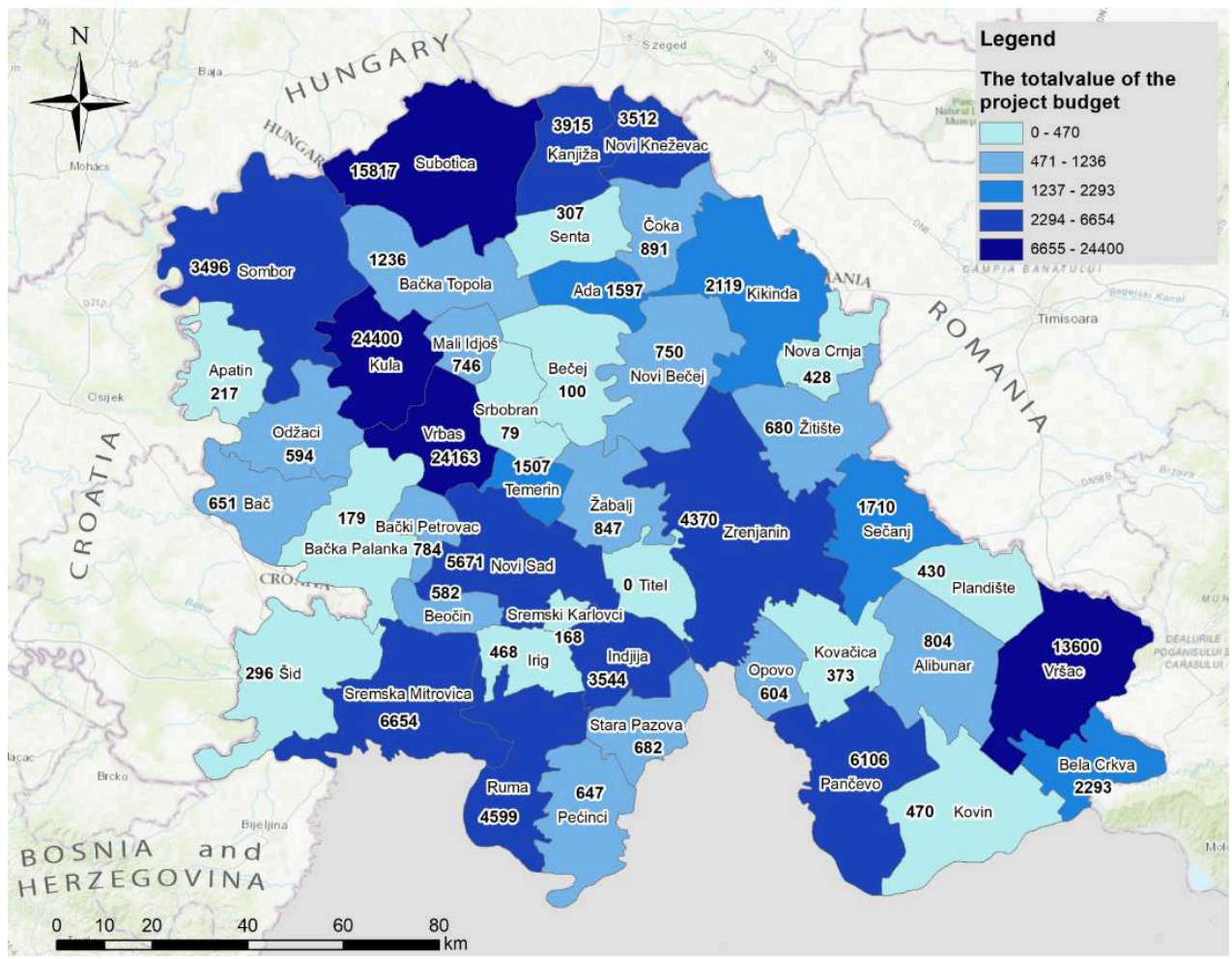

Source: On the basis of Nagy M. (2016) by the author 
Figure 4. Total value per capita of IPA sources for municipalities (IPA projects $1^{\text {st }}$ and $2^{\text {nd }}$ components) by communities in Vojvodina AP, 2007-2013.

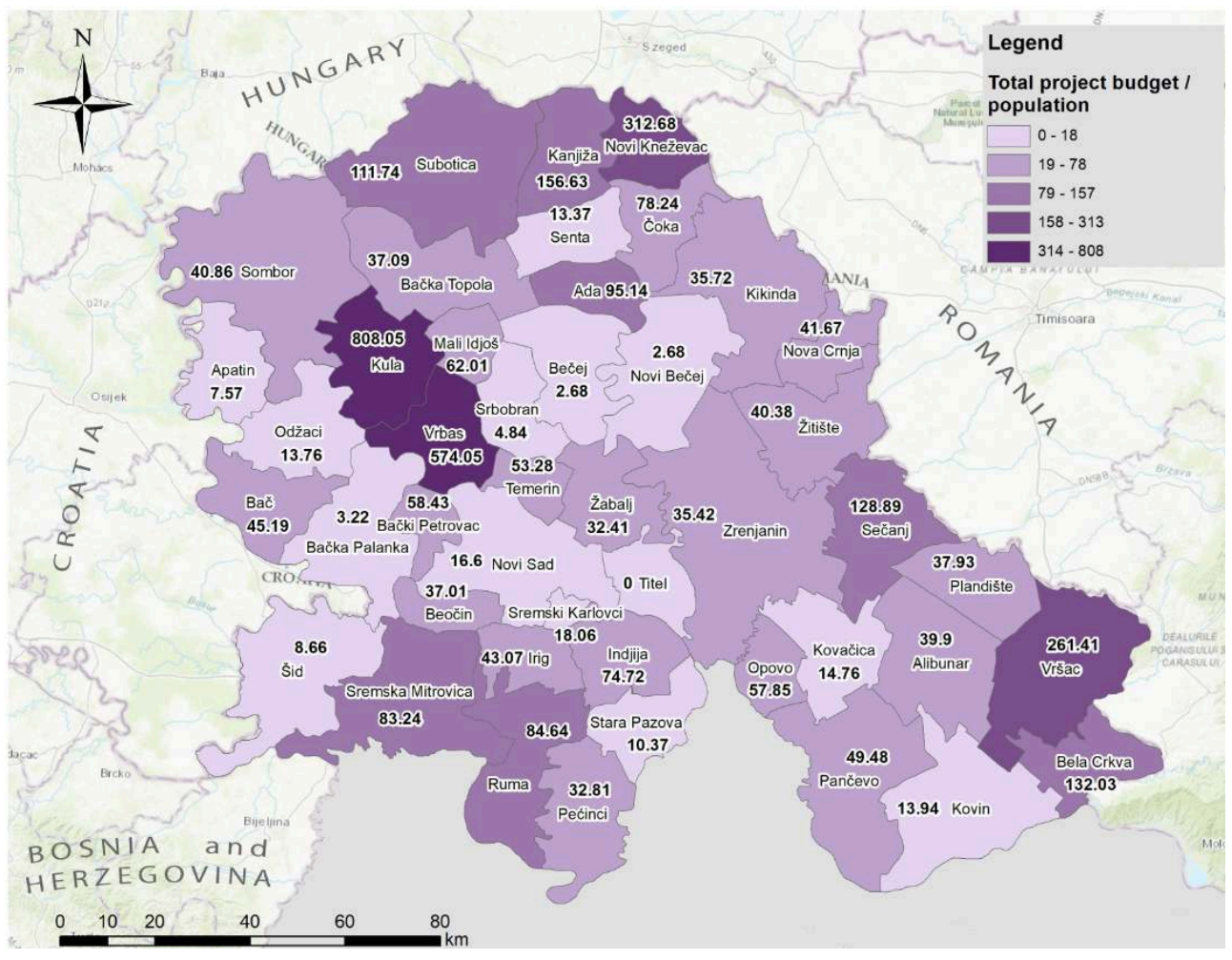

Source: Nagy M. (2016)

Determining the total amount of projects is difficult because there is no consistent record of the projects belonging to different programmes. Based on the above mentioned study, the total value of EU projects in which Vojvodina municipalities participated in the period between 2007 and 2013 is EUR 120,575,188.29. It is estimated that about two thirds of this amount were realised in municipalities from Vojvodina.

In case of the $1^{\text {st }}$ component of IPA program, many municipalities applied because in this case no foreign partnership was needed, which could have made it difficult to apply. In case of the $2^{\text {nd }}$ component of the $\mathrm{CBC}$ program, bordering communities were predominant, especially in the Hungarian-Serbian program that involved the entire territory of Vojvodina (Nagy M., 2016). No one has applied, for example, for the European Instrument for Democracy and Human Rights, the Lifelong Learning or the Youth in Action programmes. The Innovation and Competitiveness Framework Programme (CIP) was used only by the City of Novi Sad and the FP7 funds were only applied for by Novi Sad and Subotica. Only a few municipalities (e.g. Subotica, Ada etc.) applied for Europe for Citizens programme, but there were a lot more successful project applications in the EXCHANGE I-IV ${ }^{8}$, RSEDP ${ }^{9}$ or DILS ${ }^{10}$ programmes.

The typology based on economic development and project absorption capacity shows that municipalities and cities with a high level of development have further increased their advantage over other settlements thanks to EU grants. Settlements in the border area have also gained an advantage over other settlements (Figs. 2, 5). This applies mainly to the IPA CBC programs of Hungary-Serbia and Croatia-Serbia, while the projects of the Romania-Serbia program were mainly concluded by big cities (e.g. Pančevo, Vršac), where the less developed villages of the immediate border area could 
not take advantage of the programs. In connection with the north-south axis of Vojvodina, an area of underdeveloped municipalities far from the border sections is outlined well, which has little or no project absorption capacity (Ricz, 2018).

Concerning the allocated funds, there is a slight difference in financial respect (Fig. 3) compared to the figure on the number of projects (Fig. 2), as some costly infrastructure investments have given significantly greater weight to the municipalities (e.g. Kula, Vrbas, Vršac, Novi Kneževac). This difference can also be clearly seen in the figure analysing the EU funds per capita (Fig. 4), where infrastructure investments highlight certain municipalities (sewer in Kula, Vrbas, and construction of bicycle path in Novi Kneževac).

Figure 5. Relationship between the development level and the project absorption capacity of the municipalities and towns of Vojvodina.

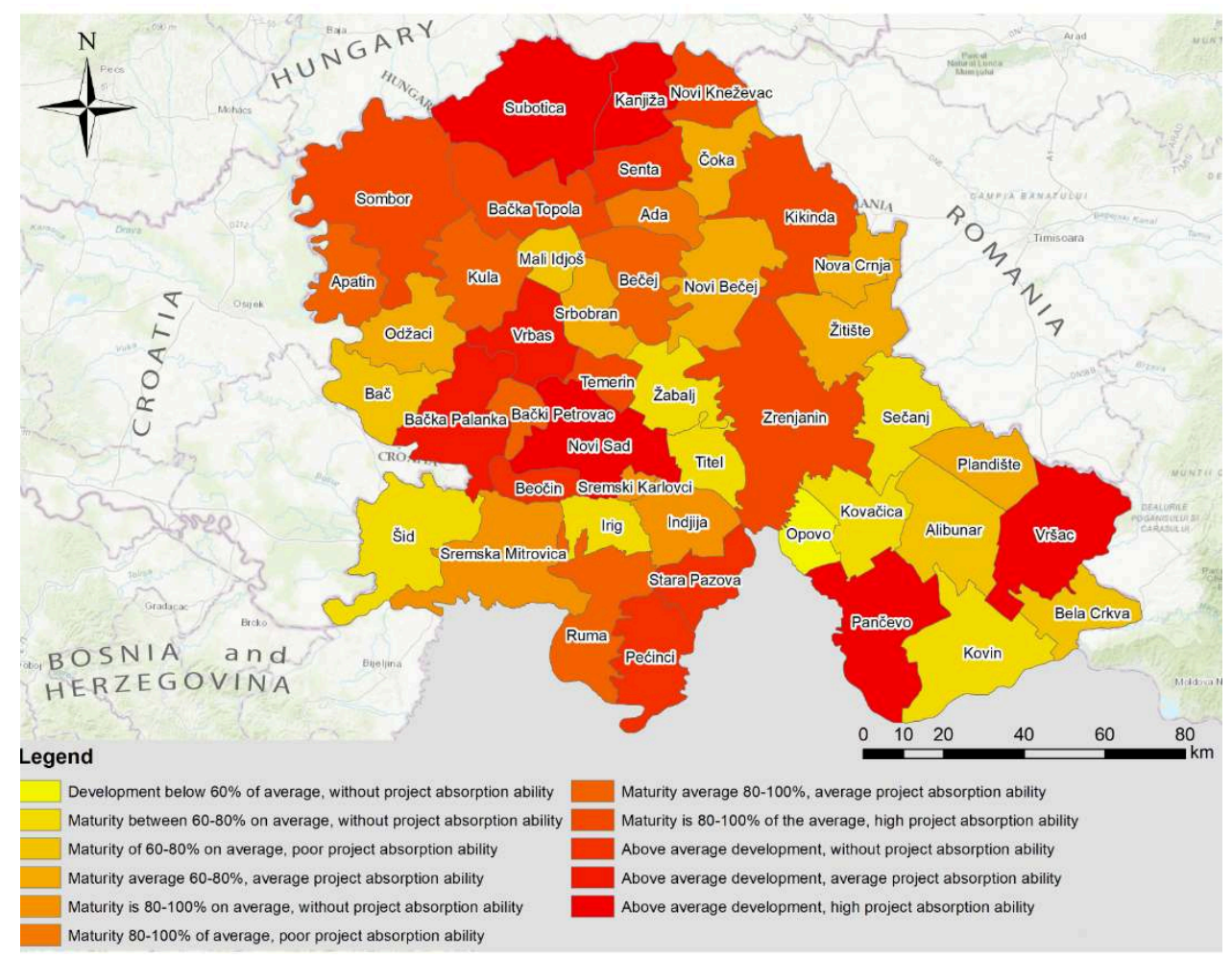

SOURCE: RICZ, 2018

During the deep-drilling analysis of the 10 involved municipalities, only those data of these towns have been taken into account, which make it possible to assess the impacts of the EU subsidies.

28 A partnership significantly determines the implementation of EU principles in the project generation phase. Such partnership usually does not end up after the project implementation; but the relationship is maintained at protocol level or at the level of new project relations. The financial sustainability of a project often depends on previous partnerships between municipalities, but the lack of human resources can also reduce functional relations between partners. Acquiring partnerships and working together for perfect implementation is hampered by partners from EU countries who, beyond $\mathrm{CBC}$ programs, have stronger European resources by the implementation of projects within operational regional programs funded by the EU. 

involvement of new partners, which is a positive consequence of the project generation process. In few cases the partnership works successfully apart from project activities even after the project development and implementation is finished. For example, after the restoration of the Synagogue in Subotica, the investor and constructor partners from Szeged (engineers, architects) were interested in the continuation of the program. Similarly, after the construction of Bajmok-Bácsalmás border crossing the Provincial Urban Planning Institute urged further cooperation with the Hungarian partner (Nagy et al., 2015). We can state based on these projects that there are multipolar (active) and unipolar (passive) forms of networking. In the first case, in the period after project closure, new partners join the lead partner for further examination and detailing of the project subject (e.g. Cooperation between Temerin (SRB) and Jánoshalma (HU) municipalities). During this process, the circle of interested municipalities, their relations become closer, which leads to micro or macro-regional development. This fact can prove successful sustainability of a project. The elements of the network make new connections independent of the project partner institutions, thus generating new connections and development. One variation of such networks is the one-sided network, when it happens only on one side of the border, without foreign partners' cooperation (there is no significant cohesive power), but with strong networking power within the country. A simpler type of network is the single-centre network where the beneficiary partner (who got the subsidy) gathers new partners and interested parties, making the core of the subsidised activity, and new development ideas and their realisation generate from here.

Project sustainability means its subsequent development generating effect after its completion. It could be followed only in $53 \%$ of the realised projects of the examined municipalities, and the immanent impact of these projects can be achieved in the medium term. In case of infrastructure projects it is easier to track sustainability as these investments are completed after several cycles (planning, construction). Some examples are the constructed bicycle trails between HU border settlements - state border - SRB border settlements. We can also enumerate some negative examples, like a number of "EXCHANGE I-IV" programme projects, which were intended to assist local authorities with the introduction of information technology (e-administration, application of geographic information systems etc.), but were not implemented in everyday use. Based on the survey with the sustainability indicators used above, it can be stated that the sustainability indicators of the projects of the examined municipalities were between 1.25 and 3.25, despite the fact that the financial realisation reached $80-100 \%$ (Nagy et al., 2015).

In terms of financial realisation, the majority of the examined towns scored $80-100 \%$ Reduced financial closures can be triggered by bank transactions and exchange rate fluctuations, but they are often due to shortcomings in tenders, causing reduced reimbursement of pre-financed items.

The experience of European countries suggests that the initial enthusiasm for crossborder cooperation often declines before cooperation can produce tangible results. Cross-border cooperation is a complex process that requires much more time to produce measurable results than the process of cooperation between local governments within a country (Bufon-Markelj, 2010). This statement is confirmed in 
practice by the project process in Vojvodina. In most cases, there is no planning in advance at local government level, and searching for partners is done ad hoc. Scientific institutions, universities and higher levels of self-government are more practically trained in this regard.

Based on the opinion of project participants, the following conclusions can be drawn from the implementation of EU funds in the municipalities of Vojvodina:

- In municipalities the approach to project writing, participation in EU projects and project implementation largely depends on the willingness of individuals to initiate, from the responsible administrative leaders in local governments or from those who see a chance in certain issues of EU regional policy;

- It is difficult to force individuals to take part in project writing if it is not their job;

- Project designers and implementers have to work overtime without any financial implications;

- The project writers are not always interested in the topics;

- The project designers do not see the importance of the development of the municipalities;

- There is no proper political interest behind the project generation;

- Often these projects are considered as sources of money laundering in local governments;

- They do not recognise the importance of the resources necessary for the implementation of strategic plans, and for education and training;

- Municipal employees have no capacity for project writing and / or do not know the language of project proposals (English), or they do not know the national and European legal-strategic frameworks and documents.

\section{Conclusion}

The research process for determining the impact of EU funds on local and regional development of Vojvodina and municipalities in Vojvodina has started in the last years of the IPA 2007-2013 project period, by harmonizing databases made using different methodologies. The analysis and processing of these databases yielded images of spatial differences in municipal financing, spatial connections in symmetrical trans-border space, while the combination with statistical indicators produced two different typologies related to EU funding in municipalities.

By identifying 10 municipalities whose participation in the use of EU funds was of varying intensity, their activities and their projects were analysed in terms of partnerships, networking, sustainability and financial realisation. Interviews were conducted with financial, economic, strategic and planning experts in local governments.

As a conclusion we can say that although substantial sums were invested from the above mentioned resources into the economy of Vojvodina for its development, it is not registered either in the increase of the local annual budget of the municipalities, or in the sum of the GDP of Vojvodina (GDP in Vojvodina between 2007-2013 was USD $8,500-9,000$ per capita, that is $35 \%$ of the EU (27) average).

Although economic development received expressed priority in the preparation of the described EU programmes, in practice they produced no considerable economic development. And while successful projects were correctly implemented in most cases, 
it was impossible to indicate their long-term effects beside short-term impacts, since many of them were only "soft" projects.

Despite the fact that EU cross-border programs did not bring about economically and financially significant changes, they had a significant impact on the applying organisations that could use the opportunity to become familiar with EU programs. Successful implementation of the projects has shown which communities are sustainable and what makes good project ideas that can be developed further. The achieved results provided a good example to others of what EU funds mean and what the benefits they bring to the development of Vojvodina.

\section{BIBLIOGRAPHY}

BLATTER J., CLEMENT N. (2000), “Cross-Border cooperation in Europe: Historical Development. Institualisation and Contrasts with North America”, Journal of Borderlands Studies, XV, 1 pp. 15-53. BUFON M., MARKELJ V. (2010), "Regional Policies and Cross-Border Cooperation: New challenges and new development models in Central Europe”, pp. 24-27, http://rrgp.uoradea.ro/art/ 2010-1/02_OK_Bufon+Markelj.pdf.

Cohesion policy 2007-13 Commentaries and official texts, Objective 3, Regulation 1082/2006/EC.https:// ec.europa.eu/regional_policy/sources/docoffic/official/regulation/pdf/2007/publications/ guide2007_en.pdf.

ĆURKOVIĆ V., MIJAČIĆ D. (2012), Impact Assessment of EU Financial Assistance to the Republic of Serbia: Time for Change, InTER, Beograd.

Evropa u Vojvodini: pogled i analiza realizovanih projekata lokalnih samouprava na teritoriji AP Vojvodine finansiranih od strane EU u programskom periodu 2007-2013, Novi Sad, Nezavisno društvo novinara Vojvodine, 2015.

FEJES ZS. (2013), "Republic of Serbia towards the European territorial cohesion and cross-border cooperation - with special focus on Vojvodina", Deturope - The Central European Journal of Regional Development and Tourism, $5,3$.

NAGY I., RICZ A., RIBÁR GY. \& NAGY M. (2015), “Spremnost i pripremljenost lokalnih samouprava AP Vojvodine za prijem $i$ korišćenje razvojnih fondova Evropske unije" (Willingness and preparedness of local self-governments of AP Vojvodina for receiving and using EU development funds), Temerin, Prospero - Temerinske novine.

NAGY M. (2016), “Apsorpcioni kapaciteti vojvođanskih lokalnih samouprava u odnosu na pretpristupne fondove”, Master Thesis, Novi Sad, Faculty of Civil Engineering (Manuscript).

NAGY I. (2018), "Different types of cross-border cooperation networks between communities on the external borders of the EU (Case studies: Serbia and neighbouring countries)", IbadanCotonou, BRIT XIV Conference, 2018 (Manuscript).

NELLES J., WALTHER O. (2011), "Changing European borders: from separation to interface? An introduction", Articulo Journal of Urban Research, 6. 
PERKMANN M. (2003), “Cross-Border Regions in Europe: Significance and Drivers of Regional Cross-Border Co-operation”, European Urban and Regional Studies, 10, 2, pp. 153-171.

POPESCU G. (2008), "The Conflicting Logics of Cross-Border Reterritorialization: Geopolitics of Euroregions in Eastern Europe”, Political Geography, 27, 4, pp. 418-438.

RICZ A., NAGY I. \& JUHÁSZ B. (2015), “A Vajdaságban elérhető gazdaságfejlesztési eszközök és az azok által elért eredmények”, in FÁBIÁN A., BERTALAN L. (eds.), Otthon a Kárpát-medencében: Területfejlesztési Szabadegyetem, Sopron, Nyugat-magyarországi Egyetem Kiadó, pp. 389-414.

RICZ A., NAGY I. \& CSISZÁR M.A. (2016), “Case study of cross-border cooperation along the Serbian - Croatian border CBC between twin towns Subotica and Osijek", in CENTRAL EUROPEAN SERVICE FOR CROSS-BORDER INITIATIVES (ed.), Crossing the borders: Studies on cross-border cooperation within the Danube Region, Budapest, Hungary, Central European Service for CrossBorder Initiatives, Part 2/12, $36 \mathrm{p}$.

RICZ A. (2018), “A határon átívelő programok hatásai a Vajdaság területi fejlődésére/The effects of cross-border cooperation programs on Vojvodina's regional development", Budapest, Tér és Társadalom, 32, 1, https://doi.org/10.17649/TET.32.1.2877.

SCOTT J.W. (2015), "Bordering, Border Politics and Cross-Border Cooperation in Europe", in CELATA F., COLETTI R. (eds.), Neighbourhood Policy and the Construction of the European External Borders, GeoJournal Library 115, https://www.researchgate.net/publication/

300787927_Bordering_Border_Politics_and_Cross-Border_Cooperation_in_Europe [accessed Jan. $31,2020]$.

SCOTT J.W. (2000), “Transboundary Cooperation on Germany’s Borders: Strategic Regionalism through Multilevel Governance", Journal of Borderlands Studies, XV, 1, pp. 143-167.

TAKÁCS Z. (2008), “Területi szerveződés és regionalizáció Szerbiában”, in GÁBRITY MOLNÁR I., MIRNICS Zs. (eds.), Regionális erőnlét. A humánerőforrás befolyása Vajdaságban, Szabadka, MTT Könyvtár 13.

"Uredba o utvrđivanju jedinstvene liste razvijenosti regiona i jedinica lokalne samouprave za 2014. godinu, Službeni list Republike Srbije 104/2014" (Decree on the establishment of a single list of development of regions and local self-government units for 2014), Official Gazette of the Republic of Serbia, 104/2014.

VOVENDA A.V., PLOTNIKOV V.A. (2011), "Euroregions as a factor of successful international integration in modern conditions", Baltic Region, 4, pp. 49-55.

https://doi.org/10.5922/2079-8555-2011-4-6.

http://www.rsedp2serbia.eu.

https://vojvodinahouse.eu/en/kancelarija-u-briselu/stranica/2/o-vojvodini.

\section{NOTES}

1. Instrument for Pre-Accession Assistance Programme - IPA.

2. Croatia became EU Member State in 2013.

3. Poland and Hungary: Assistance for Restructuring their Economies - PHARE.

4. Community Assistance for Reconstruction, Development and Stabilisation - CARDS adopted with the Council Regulation (EC) No 2666/2000. is the EU's main instrument of financial assistance to the Western Balkans, 
5. European Grouping for Territorial Cooperation is a European Union level form of transnational cooperation between countries and local authorities with legal personality.

6. Have not been included e.g. universities, NGOs, nature conservation institutes, etc.

7. Local self-governments are classified into 5 development groups ( $1^{\text {st }}$ degree of development municipalities above the average of Serbia, $2^{\text {nd }}$ degree of development - in the range of $80 \%$ to $100 \%$ of the average of Serbia; $3^{\text {rd }}$ degree of development - in the range of $60 \%$ to $80 \%$ of the national average and the $4^{\text {th }}$ group of municipalities - below $60 \%$ of Serbia's average. The $5^{\text {th }}$ group includes devastated areas which, by development, are below 50\% of the 2014 national average.

8. Exchange Programme is funded by the European Union from IPA $1^{\text {st }}$ Component.

9. Regional Socio-Economic Development Programme is funded by the European Union from IPA $1^{\text {st }}$ Component.

10. Delivery of improved Local Services (DILS) Project.

\section{ABSTRACTS}

The paper presents the various network types between municipalities/settlements within a single project program and at the level of all other analysed border programs in EU border regions that are components of European Territorial Cooperation. It also shows examples of prosperous cross-border networks (Serbia-Hungary, Serbia-Croatia, Serbia-Romania, SerbiaBulgaria) of interested communities: what positions they have and what the weight of the border settlements is in the network of cooperation in horizontal sense. Furthermore, it discusses differences of network types of cross-border cooperation of municipalities based on financial assistance from EU, IPA ${ }^{1}$ funds (2007-2013) in Vojvodina/Serbia as a border region at the external border of EU. The paper tries to define its spatial differentiation on the basis of number of applications and the amount of financial aid, as well as to present different degrees of involvement of border municipalities/settlements in cross-border cooperation with the municipalities of the neighbouring EU regions.

L'article aborde la question des différents types de réseaux reliant municipalités et agglomérations dans des programmes individuels ainsi qu'au niveau de l'ensemble des programmes analysés dans le cadre de la Coopération Territoriale Européenne. Il analyse également certains exemples de réseaux transfrontaliers performants (Serbie-Hongrie, SerbieCroatie, Serbie-Roumanie, Serbie-Bulgarie), ainsi que la position et le poids des agglomérations frontalières dans les coopérations horizontales. Nous analysons ensuite les différences entre les types de réseaux de coopération transfrontalière des municipalités sur la base de l'aide financière de l'UE, les fonds IAP (Instruments d'Aide à la Pré-Adhésion) (2007-2013) dans la province de Voïvodine (Serbie), zone située sur une frontière extérieure de l'UE. L'article vise à en définir la différenciation spatiale à partir du nombre d'applications et du montant de l'aide financière accordée, mais aussi à présenter les différents degrés d'implication des municipalités/ agglomérations concernées dans la coopération transfrontalière avec celles des régions voisines appartenant à l'UE. 
INDEX

Mots-clés: frontières extérieures de l'UE, coopération transnationale, fonds IAP, Voïvodine, Serbie

Keywords: external border of EU, cross-border cooperation, IPA funds, Vojvodina, Serbia

\section{AUTHOR}

\section{IMRE NAGY}

University of Novi Sad/Serbia, Department of Geography, Tourism and Hotel Management, imre.nadj@dgt.uns.ac.rs 